\title{
The organization of flash electroretinography unit in Veterinary Medicine
}

\author{
Organização de uma unidade de eletrorretinografia flash em Medicina Veterinária
}

\section{Cristiane dos Santos Honsho ${ }^{1}$ Arianne Pontes Oriá ${ }^{1}$ Luiz Paulo da Veiga Monteiro Lazaro Júnior ${ }^{2}$ Francisco Dorea Neto ${ }^{1}$ José Luiz Laus $^{3}$}

\section{ABSTRACT}

Electroretinography is the technique that allows the evaluation of changes in electrical potential that occur when the eye is stimulated by light. Such changes reflect the response of several retinal cells including photoreceptors (cones and rods). Thus it evaluates the retinal functionality and can diagnose abnormalities in retinas seem to be normal by ophthalmoscopy. Due to the constant evolution in veterinary ophthalmology, new centers of retinal electrophysiology have been introduced around the world either for early diagnosis of retinopathies or for preoperative evaluation of animals with cataracts and glaucoma, as well as for continuing research. The Ophthalmology Unit of the "Governador Laudo Natel" Veterinary Teaching Hospital, in the Faculty of Agronomic and Veterinary Sciences (FCAV) - Sao Paulo State University (UNESP) Jaboticabal Campus, Brazil, supported by the Fundação de Amparo à Pesquisa do Estado de São Paulo - FAPESP (Sao Paulo State Foundation for Research), set up the Unit of Ocular Electrophysiology for animals in order to provide conditions for the diagnosis of retinopathies. As a pioneering venture in Brazil, the organization of the services faced many challenges till the moment it was set up: the organization and arrangement of appropriate rooms, independent electrical distribution for the installation of separate pieces of equipment, adaptation of containment tables, training and qualification of the staff, and the elaboration and standardization of anesthetic and stimulation protocols. The wealth of information generated by our experience gave us the inspiration to write this paper, which aims to contribute to the work of researchers and veterinary ophthalmologists in this new and opportune field of specialization.

Key words: electroretinography, retina, electrophysiology, dogs.

\section{RESUMO}

Eletrorretinografia é a técnica que possibilita observar mudanças no potencial elétrico, que ocorrem quando o olho é estimulado pela luz. Tais mudanças refletem a resposta de várias células retinianas, incluindo os fotorreceptores (cones e bastonetes). Com ela, portanto, é possivel avaliar a funcionalidade da retina e diagnosticar alterações, mesmo em retinas normais à oftalmoscopia. Em face do crescente desenvolvimento da oftalmologia, no âmbito da Veterinária, novos centros de eletrofisiologia da retina vêm sendo implementados em todo o mundo, tanto para o diagnóstico precoce de retinopatias, como para avaliação pré-operatória de animais com catarata e glaucoma ou, ainda, direcionados à pesquisa. A Unidade de Oftalmologia do Hospital Veterinário "Governador Laudo Natel", da Faculdade de Ciências Agrárias e Veterinárias (FCAV) Universidade Estadual Paulista (UNESP) - Campus de Jaboticabal, com o apoio da Fundação de Amparo à Pesquisa do Estado de São Paulo - FAPESP, visando a implementar condições diagnósticas em retinopatias, implantou a Unidade de Eletrofisiologia da Retina para animais. Por ser empreendimento pioneiro, no Brasil, sua organização passou por inúmeras intercorrências até que fosse consignado. Entre elas, a organização e montagem de salas apropriadas, distribuição elétrica independente para a instalação de equipamentos, visando a diminuir interferências externas, adequação de mesas de contenção, treinamento e habilitação de pessoal, elaboração e padronização de protocolos anestésicos e de estimulação, entre outras. A riqueza de informações e as experiência geradas obstinam a conceber este trabalho que visa a contribuir com pesquisadores $e$ oftalmologistas veterinários neste, recente e oportuno, campo de especialização.

Palavras-chave: eletrorretinografia, retina, eletrofisiologia, cães.

${ }^{1} \mathrm{PhD}$ candidate, Veterinary Surgery Program, Faculty of Agronomic and Veterinary Sciences (FCAV), Sao Paulo State University (UNESP), Campus de Jaboticabal.

${ }^{2}$ Ophthalmologist Physician, Oftalmoclínica Copacabana, Rio De Janeiro, Rua Xavier da Silveira, 45, sala 1006, 22061-010, RJ, Brazil, fone: +55 215217844 .

${ }^{3}$ Professor, Department of Veterinary Clinic and Surgery, Faculty of Agronomic and Veterinary Sciences, UNESP, Campus of Jaboticabal, Via de Acesso Paulo Donato Castellane, s/n, 14884-900, Jaboticabal, SP, Brazil. phone: +55 16320926 26..E-mail: jllaus@fcav.unesp.br. Corresponding author. 


\section{INTRODUCTION}

The search for ophthalmology units in veterinary medicine grows every year; especially the search for cataract treatment. Except for some specific conditions, the disease commonly is concurrent with diseases of the posterior segment of the globe. The decision to extract the lenses in patients with cataracts depends on the application of a pre-surgical electroretinography. Degenerative retinopathies in dogs have been often reported in connection with cataracts. The retina electrophysiology permits the recognition and characterization of acquired, congenital or hereditary disorders. Thus, the electroretinogram (ERG) permits the obtaining of information concerning the degree of functioning of retinal cells involved in the visual process. Whenever abnormal conditions are detected, it is possible to identify involved cellular elements in order to characterize the visual deficit, its origin, as well as its evolution and prognosis.

\section{RETINA}

The retina is the photosensitive film lining of the posterior segment of the globe. As a segment of the nervous system, the retina function is to capture the light stimulus and to transform it into an electrical one, which is conducted to the brain cortex in order to be interpreted (BEDFORD, 1996; SAMUELSON, 1999). The retinal division has basically two layers: the retinal pigment epithelium and the sensory retina or neuroretina(CURTIS \& LIGHTFOOT, 1993; BEDFORD, 1996; COOK, 1999; JONES et al., 2000). The neuroretina has a complex structure, composed of photoreceptors and transmission elements disposed in nine layers: the visual cell layer (rod and cone layer), the outer limiting membrane, the outer nuclear layer, the outer plexiform layer, the inner nuclear layer, the inner plexiform layer, the ganglion cell layer, the nerve fiber layer and the inner limiting membrane (SLATTER, 1990; BEDFORD, 1996; SAMUELSON, 1999; JONES et al., 2000).

There are 2 types of light-sensitive cells (photoreceptors): cones and rods (YANASE et al., 1995; SAMUELSON, 1999), which differ from each other in their function, shape and retinal distribution (OFRI, 1999). In dogs the rods predominate over cones (CURTIS \& LIGHTFOOT, 1993; MILLER \& MURPHY, 1995; SAMUELSON, 1999) and act in low illumination conditions (scotopic vision) (SAMUELSON, 1999). The rods are characterized by poor visual resolution (MILLER \& MURPHY, 1995; OFRI, 1999;
SAMUELSON, 1999), and no color perception (OFRI, 1999). They are extremely sensitive to alterations in light levels and motion perception (OFRI, 1999) and are located in larger numbers in the peripheral retina (KOCH \& RUBIN, 1972; SLATTER, 1990; SAMUELSON, 1999). Rhodopsin, a rod photo-pigment in $\operatorname{dogs}$, has a peak sensitivity to light with wavelengths between 506 and 510nm, quite common to animals adapted to dim light (ACLAND, 1988; MILLER \& MURPHY, 1995).

The cones represent $5 \%$ of retinal photoreceptors in dogs (CURTIS \& LIGHTFOOT, 1993), and are concentrated in the center of the retina (RUBIN, 1967; KOCH \& RUBIN, 1972; KOMMONEM \& RAITTA, 1987; SLATTER, 1990; CURTIS \& LIGHTFOOT, 1993; SAMUELSON, 1999). They are characterized by a high resolution of fine details, and by color perception; they are rapidly adapted to intense, highly repeated and long wavelength light stimuli (photopic), and present low sensitivity to small fluctuations of light intensity (CARR \& SIEGEL, 1990; NARFSTRÖM et al, 1995; OFRI, 1996a; KOMAROMY et al., 1998a; OFRI, 1999). From a morphologic view, dogs are believed to have two types of cones. One has spectral sensitivity to light; in a wavelength between 429nm and 435nm, and the other is sensitive to wavelengths around 550nm (ACLAND, 1988; CHMIELEWSKI, 1995; MILLER \& MURPHY, 1995).

\section{ELECTRORETINOGRAPHY}

Electroretinography is an electrophysiologic test that permits the detection and recognition of visual diseases (SCHAEPPI \& LIVERANI, 1977; KOMAROMY et al, 1998a). The electroretinogram (ERG) allow for the evaluation of the functional integrity of the whole outer portion of the retina and of the pigmented epithelial layer (RUBIN, 1967), and is essential for the early diagnosis of much hereditary retinal degeneration that affects dogs (RUBIN, 1967; AGUIRRE \& RUBIN, 1972; AGUIRRE, 1995; SIMS, 1999; ORIÁ et al., 2004).

There are two basic electroretinogram modalities, namely: the flash electroretinogram and the pattern electroretinogram. The flash ERG allows for the evaluation of the retina outer layers, through luminous stimulus from a stimulator source, with controllable intensity, frequency and color of stimuli. The pattern electroretinogram (PERG) consists of luminous stimuli in the form and appearance of a chessboard - on a screen composed of white and black squares that alternate under determined frequencies. The chess pattern expresses the 
functional degree of ganglion cells, which allows for the diagnosing of disorders of the innermost layers of the retina, especially those produced by glaucoma (DANTAS et al., 1995; OFRI, 1996b; KOMAROMY et al., 1998b; SIMS, 1999).

\section{FLASH ELECTRORETINOGRAM}

Electroretinography is based on both the stimulation of the retina by light, and on the registration of its response (CARR \& SIEGEL, 1990; DANTAS et al., 1995). The two basic components to obtain the electroretinogram are the stimulation and the recording system (DANTAS et al., 1995; KOMAROMY et al., 1998b; SIMS, 1999). he photo-stimulator produces light pulses with known wavelength and intensity (DANTAS et al., 1995; SIMS, 1999). It can be put directly in front of a patient, at a distance of 20 or $30 \mathrm{~cm}$, or even attached to a dome (Ganzfeld dome) where a diffuser distributes the light stimuli onto the inner surface of the Ganzfeld dome, with a uniform stimulation of the retina (OGDEN, 1994; NARFSTRÖM et al, 1995; SIMS, 1999).

The electroretinogram, during retinal stimulation, registers the difference of potential captured by electrodes arranged over the cornea (active electrode), next to the lateral canthus (reference electrode) and on the occipital crest (ground electrode) (ACLAND, 1988; LESCURE, 1993; KOMAROMY et al., 1998b). According to Ohm's Law, a voltage is produced when electrical current, generated by a potential difference, crosses a resistance (OGDEN, 1994). In this case, the retinal cells generate the electrical current that is captured in the electroretinogram. The resistance that the current has to go through is formed by the retina, cornea and vitreous extra-cellular spaces. When a part of the retina is illuminated, the retinal cells are simultaneously activated. The electrical current originating from the stimulation of retinal cells goes through the extracellular spaces - vitreous and cornea, which attribute resistance, generating in this way the voltage that is recorded on the ERG(LESCURE, 1993; OGDEN, 1994). Retinal potentials are known to be small (lower than 1 $\mathrm{mV}$ ) and difficult to visualize. The signals that are captured by electrodes must go through pre-amplifiers and differential amplifiers before they are recorded (DANTAS et al., 1995; SIMS, 1999).

During electroretinography the patient has to be motionless. So, in veterinary medicine, the necessity of pharmacological containment is understood (KOMMONEM, 1988). However anesthetics attenuate the amplitude of the ERG- analyzed components. The depressor effect of such drugs causes just a mild alteration of the amplitude of $\mathrm{a}, \mathrm{b}$ and $\mathrm{c}$ waves, especially when retinal responses to low intensity stimulus are studied (KOMMONEM, 1988).

\section{ERG FLASH COMPONENTS}

According to ACLAND (1988), CARR \& SIEGEL (1990) and LESCURE (1993), the components of the ERG showing clinical importance are: the a-wave (negative depression) and b-wave (positive deflection). The a-wave has its origin at the outer retinal layers, as a result of electrical activity of cones and rods, as well as of other cells (SCHAEPPI \& LIVERANI, 1977).

The b-wave, however, originates at the inner retinal layers (SCHAEPPI \& LIVERANI, 1977). The main component of the b-waves results from the activation of Müller cells and, less significantly, of bipolar cells (SCHAEPPI \& LIVERANI, 1977; LESCURE, 1993; SIMS, 1999). There are also the oscillatory potentials, which are small rhythmic waves from the ascendant phase of the bwave (SCHAEPPI \& LIVERANI, 1977; LESCURE, 1993; SIMS, 1990; SIMS et al., 1991; BROOKS et al., 1992; SIMS, 1999), coming from the inner nuclear layer (SIMS, 1990; SIMS et al., 1991; BROOKS et al., 1992; SIMS, 1999). In the face of high retinal circulation dependence, the sudden increase in intraocular pressure changes the latency and amplitude of such potentials (SIMS, 1999). A third negative deflection wave, named c wave, can be observed as the result of the retinal pigment epithelium electrical activity (PARRY et al., 1953; SCHAEPPI \& LIVERANI, 1977). However, under recording conditions used in veterinary medicine, the c-wave is rarely detected (ACLAND, 1988; SIMS, 1990; LESCURE, 1993).

Numerous factors can play a part in influencing the ERG: the environmental illumination, the state of adaptation of the retina, the intensity of the flash (ACLAND, 1988; CARR \& SIEGEL, 1990; DAWSON \& KOMMONEM, 1995; OFRI, 1996b), the patient's age, the anesthetic technique, both the species and breed of the animal, the quality of the recording equipment and, especially, the retinal conditions (ACLAND, 1988; SIMS, 1990; DAWSON \& KOMMONEM, 1995; OFRI, 1996b). Moreover, the quality of the solution that has been used between the contact lense electrode and cornea, the intraocular pressure, the pupilar diameter (RUBIN, 1967; KOMAROMY et al., 1998b), environmental and body temperatures and the serum levels of glucose and oxygen (KOMAROMY et al., 1998b) are also noteworthy. Having taken into account all these 
reasons, a rigorous standardization of electroretinography protocols is considered to be of the greatest importance (MILLER, 1993; AGUIRRE, 1995; OFRI, 1996b).

\section{ERG INTERPRETATION}

In order to interpret the ERG, three parameters must be considered: latency, implicit time and amplitude. Latency is understood as the time between the stimuli and the beginning of the wave. The implicit time, measured in milliseconds (msec), refers to the time between the initial stimuli and the peak of the wave in question. The amplitude is measured in micro-volts $(\mu \mathrm{v})$ and represents the measurement from the base to the apex of the wave (CARR \& SIEGEL, 1990; LESCURE, 1993; KOMAROMY et al., 1998b; SIMS, 1999).

\section{ENVIRONMENT}

The room appointed for the application of the electroretinography should not have any windows, so that it can be easily adapted to darkroom conditions. The room temperature should be a constant $25^{\circ} \mathrm{C}$. The electrical wiring should be independent and grounded, according to the standards set by the Associação Brasileira de Normas Técnicas (ABNT)(Brazilian Association for Technical Standards).

To organize these services, the following were installed in the same room: a electroretinographic unit table, which was linked to a printer as well as an auxiliary power unit in order to guarantee security should there be a power failure. The Ganzfeld dome was placed on the other table, and a mobile stretcher table was included in order to receive the animal to be submitted to electroretinography (Figure 1A). As part of the composition of the room, there were also two boxes for animal transportation, with the dimensions of $40 \times 50 \times 60 \mathrm{~cm}$, used to accommodate the patients during the phase of adaptation to the dark.

\section{ELECTRORETINOGRAPHIC UNIT}

A stimulation apparatus composed of a semiautomatic Ganzfeld ${ }^{l}$ dome, Grass type flash units, a computer for data analysis and an interface unit for generation of stimulus and acquisition of data were employed. The parameters that were used included: dome with an opening 1 (one), back light with intensity of $272.7 \mathrm{~cd}$ $\mathrm{m}^{-2}$; Grass flash with intensity of $2.35 \mathrm{~cd} . \mathrm{s} \mathrm{m}^{-2}$, calibrated at the manufacturer by a digital photometer (Digital Radiometer/Photometer, model 2550). Blue gelatin filters ${ }^{2}$ $-10 \mathrm{~dB}$ and red gelatin filters ${ }^{3}-0 \mathrm{~dB}$, are arranged in front of the flash, in order to allow the changing of both the intensity and wave length of the luminous stimuli.

Electrodes are connected to a preamplifier that sends the captured signals to the interface unit, and subsequently to an amplifier with both low-pass and high-pass filters, of $0.3 \mathrm{~Hz}$ and $500 \mathrm{~Hz}$, respectively. After amplification and attenuation, such signals are directed to a recording unit, where they are translated to graphic form and can be represented in different scales

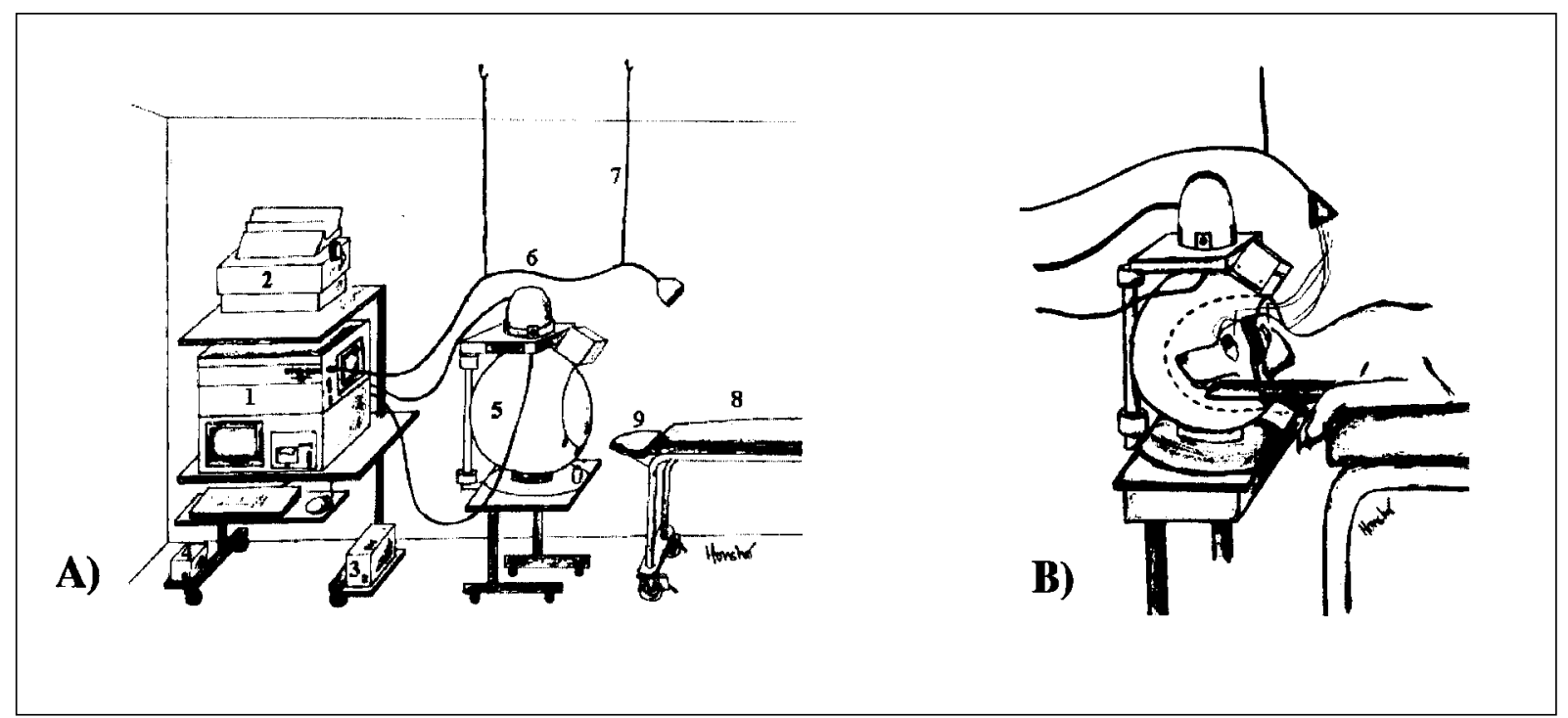

Figure 1 - Schematic representations of general disposition of equipments and materials inside the electroretinography room (A) and of the head positioning inside the Ganzfeld dome (B). 1 - electroretinographic unit; 2 - needles printer; 3 - no break; 4 - stabilizator; 5 - Ganzfeld dome; 6 - interface cable; 7 - elastic hooks; 8 - exam table; 9 - head support. 
(5mv/division, $10 \mathrm{mv} /$ division, $20 \mathrm{mv} /$ division or $50 \mathrm{mv} /$ division).

The capturing of retinal potential is possible with electrodes in ERG-jet ${ }^{\circledR}$ contact lenses, left over the cornea. Needle electrodes (ground and reference) were manually produced from $25 / 8$ and 13/4.5 hypodermic according to MUNGER's* suggestion; and from Chinese acupuncture needles ${ }^{4}(0.25 \times 25 \mathrm{~mm})$, according to LAZARO JR's** suggestion. The needles were attached to a flexible cable with a diameter of $0.35 \mathrm{~mm}$, using solder or "alligator claws", or even directly to the acupuncture needle itself. In this last case, the flexible cable was rolled up or fixed by an "alligator claw". The 6 types of electrodes are represented in figure 2 .

\section{PROTOCOLS AND METHODOLOGY}

Dogs about to be submitted to electroretinography should previously undergo a

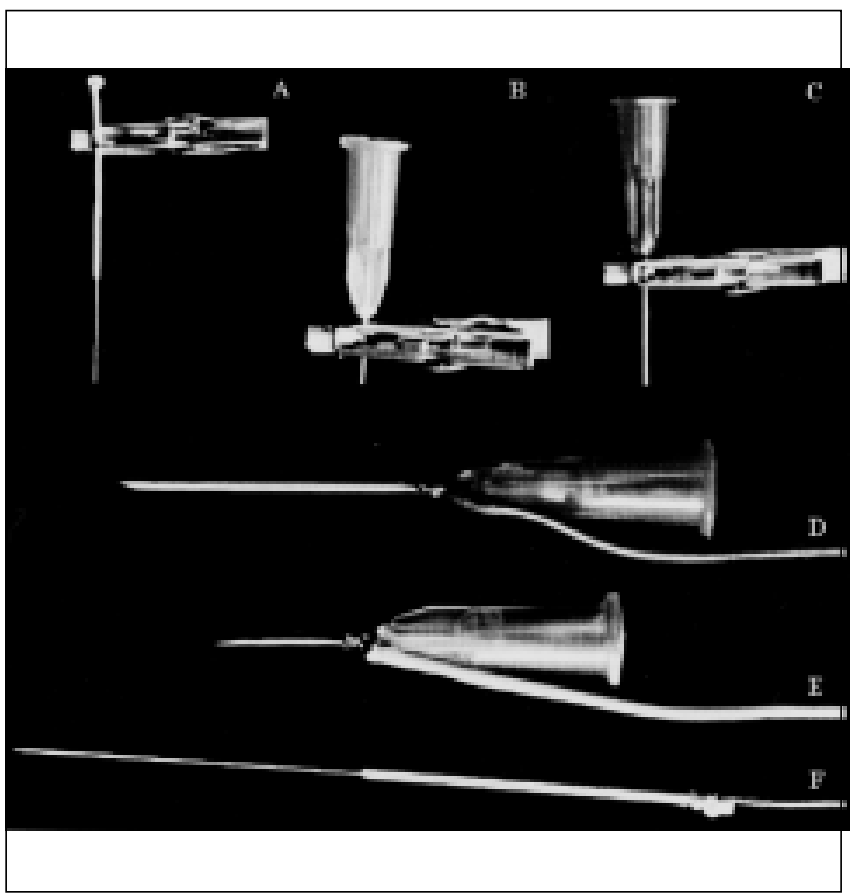

Figure 2 - Photographic image of the needle electrodes (ground and reference), which were manually manufactured. In $\mathrm{A}$, an electrode produced from acupuncture needle, attached to an "alligator-claw" for fixation of the flexible cable. In B, an electrode produced from 13/4.5 hypodermic needle, which is also fixed to the flexible cable through the "alligator-claw". In $\mathrm{C}$, an electrode manufactured from $25 / 8$ hypodermic needle, fixed to the flexible cable with "alligator-claw". In D, another electrode produced from $25 / 8$ hypodermic needle, which was soldered to the cable. In $\mathrm{E}$, an electrode manufactured from 13/4.5 hypodermic needle, also soldered to the flexible cable. In $\mathrm{F}$, an electrode produced from a Chinese acupuncture needle, surrounded by the flexible cable. physical and ophthalmic examination, as well as a complete blood cell count (CBC), biochemistry profile (creatinine, BUN and ALT) and cardiorespiratory function evaluation.

In order to carry out the electroretinography, dogs were given levomepromazine ${ }^{5}$ intravenously at a dose of $1 \mathrm{mgkg}^{-1}$ of body weight as a pre-anesthetic drug. Tropicamide chloride ${ }^{6}$ was then instilled and repeated after 15 minutes. At this point, animals were kept in transportation cages for 30 minutes to allow for adaptation to the dark. Then under room illumination arising from photophoro protected with gelatin filters, the combination of tiletamine and zolazepam $^{7}$ was given intravenously, at a dose of $5 \mathrm{mg}$ $\mathrm{kg}^{-1}$, in order to obtain a dissociative anesthesia (ORIÁ et al., 2004).

The animals were positioned in sternal recumbence under the effect of the anesthesia. In order to facilitate the fixation of electrodes and needles, the head was fixed with velcro to a head support next to the examination table. After the instillation of $0,5 \%$ proximetacaine chloride ${ }^{8}$, both eyelids were spread with Barraquer's lid speculums' ${ }^{9}$. Once the entire cornea is exposed, the corneal electrodes are applied to contact lenses permeated with 2,5\% hydroxypropyl methylcellulose ${ }^{10}$. The ground electrode is fixed to the skin next to the external occipital protuberance, and the reference electrode $1 \mathrm{~cm}$ from the left eye lateral canthus (Figure 3). To allow a uniform illumination of the retina, the head of the animal is then introduced to the Ganzfeld dome (Figure 1B) (ORIÁ et al., 2004).

Based on Classic protocol and Standard protocol, a mixed Classic/Standard protocol is proposed (Table 1). To make the interpretation of the electroretinogram easier, each signal is recorded and evaluated so that the 60 $\mathrm{Hz}$ interference occurrences are attenuated. As such, the remove interference option of the machine software, as well as a second sub-routine, named smoothing waveforms, are used to remove the excess of high frequency interference (USER'S manual EPIC-2000, 1999; ORIÁ et al., 2004).

\section{COMMENTS}

In order to minimize the obstacles that can be found when setting up electroretinography services, especially because of the lack of published data, a synthesis of the conditions for its installation is presented below. 
Infrastructure:appropriate room for electroretinography, with no windows, and a minimum area of $15 \mathrm{~m}^{2}$ in order to facilitate the movement of people and the arrangement of required material and equipment. The electrical circuit, as well as the grounding, should be isolated. An auxiliary power unit is required to provide security against power failures. This system should be allocated outside the exam room, to avoid interference. Another room adjacent to the exam room should facilitate the procedures of anesthesia. The communication between these two rooms should not impede adaptation to the dark. Room temperature should be controlled and kept at $25^{\circ} \mathrm{C}$.

Equipment and Materials: when choosing the electroretinography machine, one must consider the objectives and the operational conditions. Appropriate tables are needed to support the apparatus, the Ganzfeld dome and the animal. The tables for both the dome and the animal must be equipped with lockable wheels, which should allow for the alignment of the head of the patient inside the dome. As such, a head support must be adapted to the table where the animal will be placed with devices for fixing its head. Furthermore, in order to avoid interference, tables must not have a large metal surface. It is also suggested to fix hooks and elastic cables on the ceiling, in order to keep the interface cable hanging, thus facilitating the exam. Lanterns should have lamps protected with gelatin red filters, which will allow for better vision during the exam, however with no interference in adaptation to the dark. The choice of electrodes depends basically on the animal and where they will be used. For small and medium sized animals, contact lenses electrodes could be used, while needle electrodes could be used for large animals. Amongst needle electrodes, those made from Chinese acupuncture needles are recommended.

Human Resources: it is recommended that three people take part in the exam. These people should be knowledgeable in retinal electrophysiology, as well as anesthesiology and also the functioning and manipulation of the electroretinographic unit.

Protocols: it is expected that a variation of protocols of stimulation and registration, as well as anesthesiology, will occur from service to service, and from one laboratory to another. It is important, however, to standardize protocols that could be used in the majority of the cases.

\section{CONCLUSIONS}

According to the experience accumulated since the implantation of the electroretinography services, it is possible to conclude and advise: the

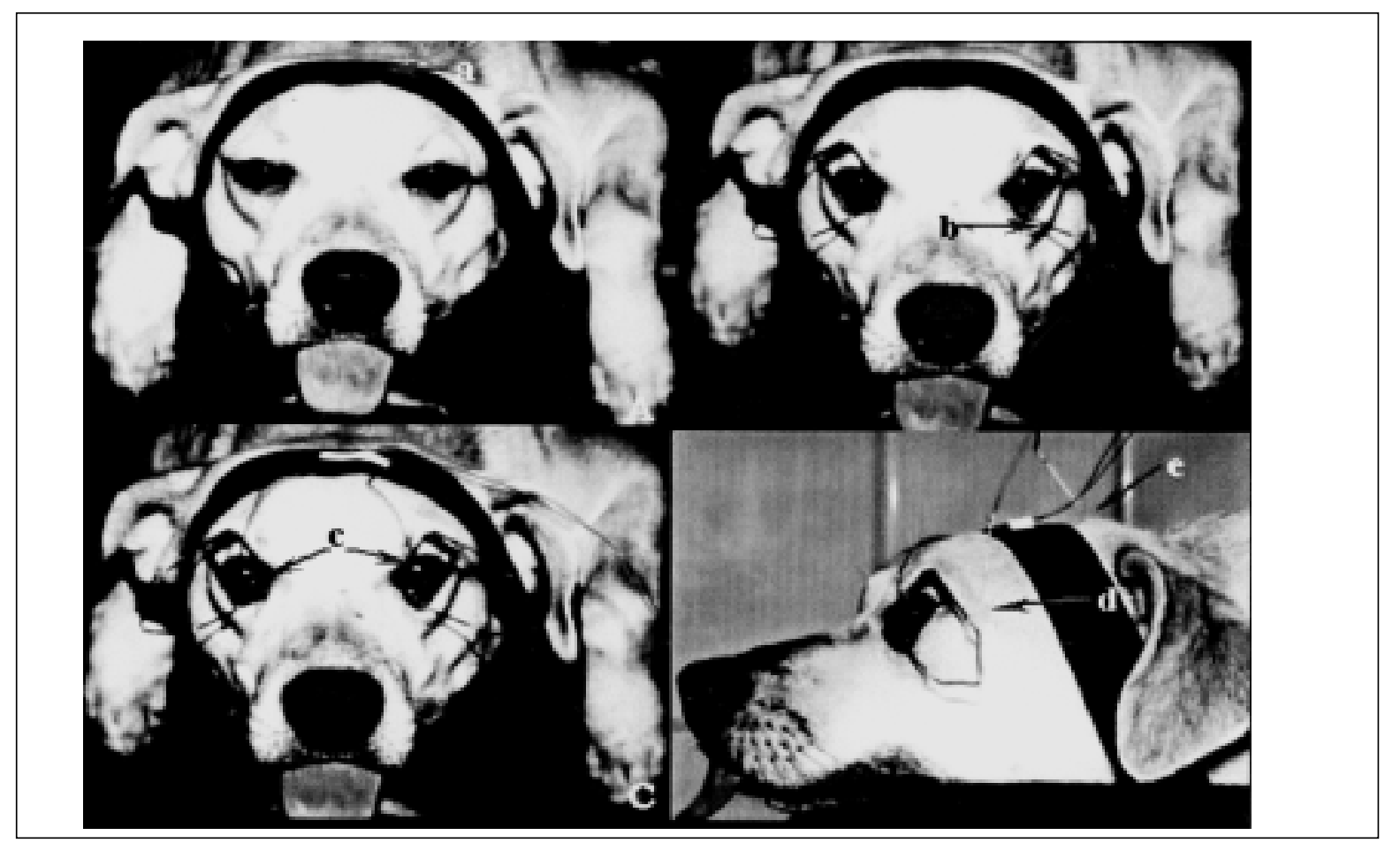

Figure 3 - Photographic image of a dog submitted to electroretinography. In A, one can see the fixation of head on the support with a velcro (a). In B, fixed blefarostate (b). In C, fixation of ERG-jet ${ }^{\circledR}$ electrodes on corneal surface (c). In D, lateral image with evidence to the positions of needle electrodes reference (d) and ground (e). 
necessity of an exclusive room for the application of the electroretinogram. This room should be provided with adequate electrical wiring, as well as an adjacent room in order to allow animals to adapt to the dark environment. The choice of an easily operated electroretinographic unit, which should be able to perform several electrophysiological tests, and the use of the Ganzfeld dome should be considered, which permits a stimulation of the entire field. The standardization of protocols that are possible to carry out and to reproduce with the utilization of secure anesthetic protocols. The availability of non-traumatic registration electrodes, which could be applied to different animals, moreover the necessity of qualified staff, with the knowledge of retinal electrophysiology, and precision expertise in the functioning of the available equipment.

\section{SOURCES AND MANUFACTURERS}

1-2503B - LKC Technologies Inc.

${ }^{2}$-Kodak Wratten $\mathrm{n}^{\circ} .98,450 \mathrm{~nm}, 1,1 \mathrm{~Hz}$

3 -Kodak Wratten $n^{\circ} .29,630 \mathrm{~nm}, 5,1 \mathrm{~Hz}$

${ }^{4}$-Suzhou Huanqiu Acupuncture Medical Appliance Co. Ltd.

${ }^{5}$-Neozine ${ }^{\circledR}$ - Rhodia farma Ltda.

6-Mydriacil - Alcon Laboratórios do Brasil Ltda.

${ }^{7}$-Zoletil ${ }^{\circledR}$ - Virbac do Brasil Ind. e Com. Ltda.

${ }^{8}$-Anestalcon ${ }^{\circledR}$ - Alcon S/A.

9-Blefarostato Barraquer-N.J.Petrovich instrumentos Cirúrgicos.

${ }^{10}$-W-GPS ${ }^{\circledR}$ - Wilson Ophthalmic.

*MUNGER, R. J. (Animal Ophthalmology Clinic, Dallas- Texas - USA). Personal comunication, 1999

** LAZARO JÚNIOR, L.P. (Oftalmoclínica Copacabana, Rio de Janeiro - RJ - Brazil). Personal Comunication 2000

\section{ACKNOWLEDGMENTS}

FAPESP - research grants process 98/03153-0.

CAPES - Master in Science scholarship.

Dr. DANIEL KAN HONSHO - drawings

Dr. MARLOS GONSALVES and JOHN BOLICIAN - English version

\section{REFERENCES}

ACLAND, G.M. Diagnosis and differentiation of retinal diseases in small animals by electroretinography. Semin Vet Med Surg Small Anim, v.3, n.1, p.15-27, 1988.

AGUIRRE, G.D.; RUBIN, L.F. Progressive retinal atrophy in the miniature Poodle: an electrophysiologic study. J Am Vet Med Assoc, v.160, n.2, p.191-201, 1972.

AGUIRRE, G. Electroretinography - Are we misusing an excellent diagnostic tool?. Vet Comp Ophthalmol, v.5, n.1, p.2-3, 1995.

BEDFORD, P. The anatomy of the canine fundus. In: CONGRESS OF THE SMALL ANIMAL VETERINARY ASSOCIATION, 21., 1996, Jerusalem. Proceedings... Jerusalem : Small Animal Veterinary Association, 1996. p.24.
BROOKS, D.E. et al. Changes in oscillatory potentials of the canine electroretinogram during acute sequential elevations in intraocular pressure. Progr Vet Comp Ophthalmol, v.2, n.2, p.80-89, 1992.

CARR, R.E.; SIEGEL, I.M. Electrodiagnostic testing of the visual system: a clinical guide. Philadelphia : F.A. Davis, 1990. 187p.

CHMiEleWsli, N.T. Special boards. Progr Vet Neurol, v.6, n.2, p.73-75, 1995.

COOK, C.S. Ocular embryology and congenital malformations. In: GELATT, K.N. eterinary ophthalmology. 3.ed. Philadelphia : Lippincott Williams \& Wilkins, 1999. p.3-30.

CURTIS, R.; LIGHTFOOT, R.M. The canine fundus. In: PETERSEN-JONES, S.M., CRISPIN, S.M. Manual of small animal ophthalmology. London : Bristish Small Animal Veterinary Association, 1993. p.237-258.

DANTAS, A.M. Eletrorretinografia. In: DANTAS, A.M. et al. Eletrofisiologia ocular. Rio de Janeiro : Cultura Médica, 1995. 322p.

DAWSON, W.W.; KOMMONEM, B. The late positive retinal potential in dogs. Exp Eye Res, v.60, n.2, p.173-179, 1995.

JONES, T.C.; HUNT, R.D., KING, N.W. Retina. In: Patologia veterinária. 6.ed. São Paulo :

Manole, 2000. p.1334-1341.

KOCH, S.A.; RUBIN, L.F. Distribution of cones in retina of the normal dog. Am J Vet Res, v.33, n.2, p.361-363, 1972 .

KOMAROMY, A.M.; SMITH, P.J.; BROOKS, D.E. Electroretinography in $\operatorname{dogs}$ and cats. Part I. Retinal morphology and physiology. Comp Cont Educ Pract Vet, v.20, n.3, p.343-350, 1998a.

KOMAROMY, A.M.; SMITH, P.J.; BROOKS, D.E. Electroretinography in $\operatorname{dog} s$ and cats. Part II. Technique, interpretation, and indications. Comp Cont Educ Pract Vet, v.20, n.3, p.355-365, 1998b

KOMMONEM, B. The DC-recorded dog electroretinogram in ketamine-medetomidine anaesthesia. Acta Vet Scand, v.29, n.1, p.35-41, 1988.

KOMMONEM, B.; RAITTA, C. Electroretinography in labrador retrievers given ketamine-xylazine anesthesia. Am J Vet Res, v.48, n.9, p.1325-31, 1987.

LESCURE, F. Électrophysiologie oculaire. Encyclopédie Vétérinaire, Ophthalmologie 1700, p.1-13, 1993.

MILLER, T.R. The uses and limitations of the electroretinogram in veterinary practice. Brit Vet J, v.149, n.3, p.3-4, 1993.

MILler, P.E.; MURPHY, C.J. Vision in dogs. J Am Vet Med Assoc, v.207, n.12, p.1623-1634, 1995.

NARFSTRÖM, K. et al. Clinical electroretinography in the dog with gazfeld stimulation: a practical method of examining rod and cone function. Doc Ophthalmol, v.90, p.279-290, 1995. 
OFRI, R. Applied retinal physiology. In: CONGRESS OF THE SMALL ANIMAL VETERINARY ASSOCIATION, 21., 1996, Jerusalem. Proceedings... Jerusalem : Small Animal Veterinary Association, 1996a. p.27.

OFRI, R. The electroretinogram - a powerful, yet often ignored, tool in the diagnosis of retinal diseases. In: CONGRESS OF THE SMALL ANIMAL VETERINARY ASSOCIATION, 21., 1996, Jerusalem. Proceedings... Jerusalem : Small Animal Veterinary Association, 1996b. p.28.

OFRI, R. Optics and physiology of vision. In: GELATT, K. N. Veterinary ophthalmology. 3.ed. Philadelphia : Lippincott Williams \& Wilkins, 1999. p.183-216.

OGDEN, T. E. Clinical electrophysiology. In: RYAN, S. J.; OGDEN, T. E. Retina. 2. ed. St. Louis: Mosby, 1994. p 321-332.

ORIÁ, A.P. et al. Considerations about electroretinography in dogs. Ciência Rural. v.34, n.1, p.323-328, 2004.

PARRY, H.B.; TANSLEY, K.; THOMSON, L.C. The electroretinogram of the dog. J Physiol, v.153, n.120, p.28-40, 1953.

RUBIN, L.F. Clinical electroretinography in dogs. J Am Vet Med Assoc, v.151, n.1, p.1456-1469, 1967.

SAMUELSON, D.A. Ophthalmic anatomy. In: GELATT, K. N. Veterinary ophthalmology. 3.ed. Philadelphia :
Lippincott Williams \& Wilkins, 1999. p.31-150.

SCHAEPPI, U.; LIVERANI, F. Procedures for routine electroretinography (ERG) in dogs. Agents Actions, v.7, n.3, p.347-351, 1977.

SIMS, M.H. Partial masking of the canine electroretinogram by oscillatory potentials - to problem of frequency bandwidth. J Vet Int Med, v.4, n.1, p.40-42, 1990.

SIMS, M.H. et al. Effects of stimulus intensity and conditioning on the electroretinogram and oscillatory potentials in darkadapted cats. Progr Vet Comp Ophthalmol, v.1, n.3, p.177$185,1991$.

SIMS, M.H. Electrodiagnostic evaluation of vision. In: GELATT, K.N. Veterinary ophthalmology. 3.ed. Philadelphia: Lippincott Williams \& Wilkins, 1999. p.483-510.

SLATTER, D. Retina. In: Fundamentals of veterinary ophthalmology. 2.ed. Philadelphia: Saunders, 1990. p.400-436.

USER'S manual EPIC-2000. Gaithersburg : LKC Technologies, 1999. 160p.

YANASE, J.; OGAWA, H.; OHTSUKA, H. Rod and cone components in the dog electroretinogram during and after dark adaptation. J Vet Med Sci, v.57, n.5, p.877-881, 1995. 